This is an electronic reprint of the original article. This reprint may differ from the original in pagination and typographic detail.

Author(s): Natri, Teija; Räsänen, Anne

Title: Developing a conceptual framework : the case of MAGICC

Year: $\quad 2015$

Version:

Please cite the original version:

Natri, T., \& Räsänen, A. (2015). Developing a conceptual framework : the case of MAGICC. In J. Jalkanen, E. Jokinen, \& P. Taalas (Eds.), Voices of pedagogical development : expanding, enhancing and exploring higher education language learning (pp. 85-102). Research-publishing.net.

https://doi.org/10.14705/rpnet.2015.000288

All material supplied via JYX is protected by copyright and other intellectual property rights, and duplication or sale of all or part of any of the repository collections is not permitted, except that material may be duplicated by you for your research use or educational purposes in electronic or print form. You must obtain permission for any other use. Electronic or print copies may not be offered, whether for sale or otherwise to anyone who is not an authorised user. 


\section{Developing a conceptual framework: the case of MAGICC}

\section{Teija Natri and Anne Räsänen ${ }^{1}$}

\section{Abstract}

$\mathrm{T}$ his paper reports the steps taken to develop the conceptual framework of the MAGICC project (2013), which aimed to provide action-oriented descriptions of multilingual and multicultural academic and professional communication competence, instructional designs to promote these in higher education language teaching, and multidimensional forms of assessment aligned with the learning outcomes established - all presented in an academic ePortfolio that expands the features of the existing European Language Portfolio (ELP) to the higher education level. "Starting with systematic desk research into the existing conceptualisations of multi/plurilingual and multi/ intercultural competences as well as lifelong learning and employability skills, the next step was to collect and analyse the data gathered from all partner institutions and existing national and European projects on descriptors already in place for academic level competences, practices and assessment. [...] To ensure the social relevance of the framework, the third step was to develop questionnaires for students, faculty, and employers and ask them to rank the synthesised skill and competence descriptors in terms of their importance for the academic and professional competences graduates would need for study purposes as well as for the global labour market. The first draft of the conceptual framework was revised on the basis of this stakeholder consultation and led to the version presented to a new group of selected stakeholders in a consultation seminar" (Räsänen 2014: 66-67).

Keywords: academic language learning, multilingual and multicultural competence, language assessment, Common European Framework of Reference, CEFR.

1. Language Centre, University of Jyväskylä, Finland; teija.natri@jyu.fi; anne.e.rasanen@jyu.fi

How to cite this chapter: Natri, T., \& Räsänen, A. (2015). Developing a conceptual framework: the case of MAGICC. In J. Jalkanen, E. Jokinen, \& P. Taalas (Eds), Voices of pedagogical development - Expanding, enhancing and exploring higher education language learning (pp. 85-102). Dublin: Research-publishing.net. doi:10.14705/rpnet.2015.000288 


\section{Introduction}

This paper presents the main steps taken to develop the conceptual framework for the project Modularising Multilingual and Multicultural Academic Communication Competence (MAGICC) $)^{2}$. The project emphasises the role of languages and communication in the construction of academic expertise and in the process of socialising graduates for international working life. The developed competences constitute transversal key competences and are "vital for living, studying and working in an internationalised knowledge-based society and economy" (Forster Vosicki 2014: 66).

Explicit development of students' multilingual and multicultural academic communication competences is needed as a strategy to contribute to the modernisation agenda of higher education (i.e. the European Higher Education Area (EHEA) and Bologna Process 2020), because these competences have not been sufficiently taken into account in the implementation of the Bologna process.

The European documents related to higher education competences and qualifications as well as to the quality of the Bologna process were used as the initial rationale for the MAGICC project. These documents describe the general core competences and expected learning outcomes for each cycle established during the Bologna process (see e.g. Bologna Working Group 2005). The most important descriptors of graduate achievement from the point of view of the project are the following:

\section{First cycle (BA):}

- "have the ability to gather and interpret relevant data [...] to inform judgments;

- can communicate information, ideas, problems and solutions to both specialist and non-specialist audiences;

- have developed those learning skills that are necessary for them to

2. http://www.magicc.eu: A Lifelong Learning Programme of the European Commission (2011-2014) 
continue to undertake further study with a high degree of autonomy" (Bologna Working Group 2005).

\section{Second cycle (MA):}

- "have the ability to integrate knowledge and handle complexity, and formulate judgments with incomplete and limited information;

- can communicate their conclusions, and the knowledge and rationale underpinning these, to specialist and non-specialist audiences clearly and unambiguously;

- have the learning skills to allow them to continue to study in a manner that may be largely self-directed or autonomous" (Bologna Working Group 2005).

These qualifications for the European Higher Education Area (EHEA) therefore focus on the graduates' ability to manage information and construct knowledge, to share one's own expertise with various audiences, as well as to have the skills and strategies for continuous independent learning. Further principles of the Bologna implementation documents are concerned with action orientation, maintenance of diversity, transparency and comparability of student achievement, as well as the social relevance of education in terms of, for example, employability and integration in society. However, as was stated above, specific attention in higher education is needed to promote students' multilingual and multicultural competences for managing global contexts of study and work (see EHEA 2012: Bologna Process Implementation Report).

Following the initial rationale above, the main purpose of the MAGICC project was to conceptualise multilingual and multicultural communication competence for the higher education level and in this way complement the Council of Europe's Common European Framework of Reference for Languages $\left(\mathrm{CEFR}^{3}\right)$ in areas that are not addressed in the CEFR. The key difference, however, is that the starting point for MAGICC is not a monolingual 
view of language and communication competence, but a view where various languages - mother tongue included - are intertwined and appear side by side in constructing the individual's interactive competence and communicative action in various social contexts. The conceptual framework and its learning outcome descriptions of general "academic, discipline-specific, professional, intercultural, and lifelong learning competences" (Räsänen 2014: 67) form the foundation for new types of instructional designs, learning activities and assessment forms. These are manifested by practical tools that were developed in the project, namely, learning tasks in the form of scenarios, transparency tools for assessment and an academic ePortfolio. With these outputs the MAGICC project forms an integrated, online reference tool for various users, from teachers and students to employers and policy- and decision-makers. Nine universities from seven European countries took part in the project:

- Université de Lausanne and Université de Fribourg from Switzerland;

- Universität Bremen and Freie Universität Berlin from Germany;

- Jyväskylän yliopisto from Finland;

- The Open University from the United Kingdom;

- Rijksuniversiteit Groningen from the Netherlands;

- Universidade do Algarve from Portugal;

- Politechnika Poznanska from Poland.

The European Centre for Modern Languages of the Council of Europe participated in the project as an associated partner.

The project tasks were divided into nine different work packages (WP) in order to provide the four envisaged tools: (1) a conceptual framework for multilingual and multicultural communication competence with specific learning outcomes for higher education and aligned assessment criteria and grids (WP1 \& WP2); (2) an academic ePortfolio to provide recognition of students' multilingual and multicultural profile and render it visible to third parties (WP3); (3) action-oriented multilingual and multicultural academic or professional communication scenarios (WP4); and (4) transparency tools to enable harmonisation of assessment (WP5). The other four WPs were 
concerned with dissemination, exploitation, quality assurance, and project coordination and management.

The University of Jyväskylä was in charge of the first two WPs: mapping the field and establishing the state of the art as well as the elaboration of the conceptual framework. This work required much collaboration and evaluation by all partners and external stakeholders who would be the potential users of the framework. The stepwise development processes are explained below. The outcomes of the processes, then, formed the basis for the work done in the other WP.

\section{Step 1: Mapping the field and establishing the state of the art}

The first task in the project was to map the field and carry out systematic desk research into existing conceptualisations of multi/plurilingual and multi/ intercultural competences, lifelong learning skills, and employability skills. Also, in this first part, the existing multilingual and multicultural learning outcome descriptions for the higher education level in use at the participating universities were collected. All this information was collected in a synthesis report for the first work package.

\subsection{Defining basic concepts}

As the MAGICC project was concerned with describing, conceptualising and integrating competences from a new perspective, an important and necessary task was to reach an agreement among the project partners on what terminology and concepts would be used in the conceptual framework. After mapping the field for existing definitions of the basic concepts, the second partner meeting (in June 2012) included a workshop during which agreements were reached on the basic concepts of the project.

First of all, there are many existing understandings of multilingualism, depending on whether the perspective is sociolinguistics, communication, 
identity, cognition, translation, learning, or agency and participation. The older conceptualisations saw multilingualism as multiplied monolingualism, where languages were present as bounded entities, each with a defined system of its own, and one language was used at a time. Recent views see languages as resources for social and other actions, in other words, people use their multilingual resources in their local contexts, often simultaneously, interacting with the context. Furthermore, new conceptualisations (for an overview, see Lähteenmäki, Varis \& Leppänen 2011) emphasise the fact that multilingualism needs to be seen as language resources that may be heterogeneous and represent independent profiles and that are mobilised by individuals and groups with different effects and outcomes. In addition, recent sociolinguistic research approaches multilingualism as a dynamic repertoire of linguistic and discursive resources an individual may use without experiencing that there are separate languages or varieties within it (heteroglossia, in Leppänen), and that the repertoire never represents whole languages but only those resources which have become accessible through life experience (truncated multilingualism, comprising e.g. certain genres and registers, in Blommaert, Collins \& Slembrouck 2005) or which are available and necessary in pursuing certain communicative goals (polylingualism and translanguaging, in Jørgensen 2008, Møller 2008; all references are from Lähteenmäki et al. 2011). In these conceptualisations, the Council of Europe distinction between the terms multilingual (about communities) and plurilingual (about individuals) ${ }^{4}$ is not explicitly made.

If multilingualism has been a complicated concept to handle and define, so has the term multicultural. Existing definitions, again depending on the perspective and context, have listed pluricultural, intercultural, multicultural and inter/ pluriculturality as related concepts. Because the European Commission uses the term multilingual/multicultural to refer to either individual- or community-level usage, we could not adopt the Council of Europe distinction between pluricultural

4. The Council of Europe definition of plurilingualism: "lifelong enrichment of the individual's plurilingual repertoire [...,] made up of different languages and language varieties at different levels of proficiency, including different types of competence. [....] A person's plurilingual competence changes in its composition throughout one's life. [...] A plurilingual person has a repertoire of languages and language varieties as well as competences of different kinds and levels within the repertoire" (Council of Europe: Language Policy Division 2006, http://www.coe.int/t/dg4/linguistic/division_EN.asp?). 
and multicultural directly. However, it was jointly agreed that the definition of the key concepts should accommodate relevant meanings from several existing definitions and be reformulated accordingly. Thus, for example, the term multicultural in the project is defined as a combination of the pluricultural and intercultural profiles of graduates. The jointly agreed definition for the key terms in the title, then, is as follows:

\footnotetext{
"Multilingual and multicultural academic communication competence is an individual's communicative and interactive repertoire, made up of several languages and language varieties including first language(s) at different levels of proficiency, and various types of competence, which are all interrelated. The repertoire in its entirety represents a resource enabling action in diverse use situations. It evolves across time and experience throughout life, and includes growth in intercultural awareness and ability to cope with, and participate in, multicultural contexts of academic study and working life" (MAGICC Conceptual framework 2013: section 2.1).
}

General definitions for lifelong/independent/autonomous learning skills and employability/workplace/professional communication skills were also initially agreed upon among the partners. Further specification was then necessary when dealing with the data and deciding on the learning outcome descriptors. All terminological definitions are presented in the conceptual framework.

\subsection{Mapping existing learning outcome descriptions}

After agreeing on the basic terminology to be used, all partners conducted a survey on existing learning outcome descriptors related to academic, disciplinespecific, professional, intercultural and independent learning competences in use at their universities. The CEFR was also consulted for the general descriptors relevant for the academic level. In addition, related projects and good practices were mapped. These mappings provided rich data, which then had to be analysed and presented in a manageable form on the basis of the principles and terms underlying the conceptual framework. 
The survey data on academic competences could have been synthesised and categorised in many ways. For instance, a classification according to transferable academic skills or employability skills or critical thinking skills - all of which can be related to academic communication competences could have been used. Other terms often used include soft skills and generic skills or competences. However, in the end, the categorisations of academic competences and strategies presented by Adamson (1993) and Cottrell (2003) were adopted, in a slightly adapted form, because they seemed to reflect more directly what the data were showing and because the role of language and study skills was more explicit and added new elements to the CEFR, particularly in terms of the higher education level. Thus, the general, discipline-specific and professional learning outcomes as well as the independent learning outcomes provided by the data were synthesised accordingly. It is important to bear in mind that in real academic situations, the separate skills are developed on an integrated basis, and because of this integration there was significant overlap in the data.

The survey data also included references to and descriptions of intercultural academic communication competence, which is a key element of the MAGICC project endeavour. As was explained in the previous section above, this concept can also be described from different perspectives and includes aspects that are not easy to formulate as learning outcomes, let alone as assessment criteria. However, some categorisation principles were necessary in this case as well, because the CEFR is not very elaborate in its descriptions for the academic level. As the starting point and first reference for dealing with the data, we chose the Council of Europe's publication Assessment in Plurilingual and Intercultural Education (Lenz \& Berthele 2010), because it starts with assessment and not with a mere analysis of the abilities, skills and attitudes involved in intercultural encounters. The second framework used was that of the INCA project (2004), on intercultural communicative competence (ICC), which also includes assessment. The plurilingual approach of the CARAP project (2011) was also consulted, because it includes a comprehensive set of descriptors (for Byram's (2008) complete ICC framework, see Lenz \& Berthele 2010: 9). 
Lenz and Berthele (2010: 6) define intercultural competence as having "to do with the integration of 'otherness' in one's thinking and actions", and continue that this definition is "significantly different from a concept of pluricultural competence, which highlights the plurality of cultures one may identify and is familiar with". The first one, according to them, is not necessarily linked with knowledge of languages, because it could materialise through, for example, a lingua franca. The second concept, on the other hand, represents a default case of plurality and dynamics of languages and cultures. In this context, plurilingual (or in MAGICC terminology, multilingual), communication competence refers to "the ability to mobilise [one's] language repertoire as a whole [and] to use existing competences transversally, [that is], to recombine existing knowledge and skills in any language(s) in order to respond flexibly to needs that arise in a multilingual environment" (Lenz \& Berthele 2010: 5-6).

It seems clear, however, that intercultural competence is a prerequisite for plurilingual competence to be materialised, which is why it is treated here separately from the other sets of learning outcomes in the data. Existing learning outcomes for intercultural communication competence in the data were categorised according to the INCA (2004) descriptors, because they relate more explicitly to communication (from Lenz \& Berthele 2010: 10):

\section{1st strand: openness}

- respect for otherness (ability to look at all customs and values from a distance, regarding them at the same time as worthwhile in their own right);

- tolerance of ambiguity (ability to accept ambiguity and lack of clarity and deal with it constructively).

\section{2nd strand: knowledge}

- knowledge discovery (ability to acquire and actually use cultural knowledge); 
- empathy (ability to intuitively understand what other people think and how they feel).

\section{3rd strand: adaptability}

- behavioural flexibility (ability to adapt one's own behaviour to different requirements and situations);

- communicative awareness (ability to identify and consciously work with communicative conventions) (Lenz \& Berthele 2010: 10; cf. INCA project 2004).

Finally, the synthesis report also provided a short overview of good practice samples, scenarios, pilot approaches and assessment forms and criteria in use at the participating universities. The whole was then completed with some relevant data on descriptors already in place for academic level competences, practices and assessment from existing national and European projects (e.g. Bilingue plus 5 ; CARAP 2011; LanQua 2010; Profile Deutsch ${ }^{6}$; TNP37).

\section{Step 2: Elaboration of the MAGICC conceptual framework}

The information collected in the WP1 survey was further elaborated into a descriptive conceptual framework which contains transnationally shared learning outcomes for multilingual and multicultural academic core communication competences. The overall aim for higher education degrees presented in the quality toolkit of the Language Network for Quality Assurance (LanQua 2010) project was adopted as the basis for elaboration. This aim is expressed as follows:

\footnotetext{
5. http://www.unifr.ch/bilingueplus/fr

6. https://www.goethe.de/de/spr/unt/kum/prd.html

7. http://web.fu-berlin.de/tnp3/
} 
"The overall aim for higher education degrees is to ensure solid multilingual mastery of the discipline/field-specific and professional domain with a developed competence in lifelong learning and use of own multilingual and multicultural repertoire for effective communication and interaction as well as for self-directed learning" (MAGICC Conceptual framework 2013: section 10).

The core competences of graduates for global employability were also described in the LanQua (2010) project and they are presented in the conceptual framework. As mentioned by Räsänen (2014: 67),

"[t]he three main action-oriented, multilingual and multicultural competences established through this stepwise process for the BA and MA levels, with some variable focuses, address management of information and knowledge sources, conceptualization and communication of information and expertise, and management of learning from a lifelong perspective. They form the essence of the conceptual framework, detailed further into specific skills and strategies that combine descriptors [in line with e.g. Baume 2009 and Moon 2006] for academic, discipline-specific, professional, intercultural and lifelong learning competences and their aligned assessment".

The whole is completed by assessment criteria for improving reliability, as well as a list of innovative types of activities to scaffold the achievement of expected learning outcomes. Figure 1 below illustrates the integrated approach followed when building the MAGICC conceptual framework (2013).

The conceptual framework includes a comprehensive set of learning outcome descriptions (i.e. the minimum threshold levels to be achieved) and their multidimensional assessment forms, serving as a reference tool for language specialists and curriculum designers. The learning tasks and activities - academic and professional scenarios - are examples of the actual implementation of the framework and adaptable to various situations of developing students' competences and repertoires. 
Figure 1. The principle of constructive alignment of learning outcomes, learning tasks and alternative assessment forms and criteria in the MAGICC conceptual framework (2013, adapted from Biggs 1999)

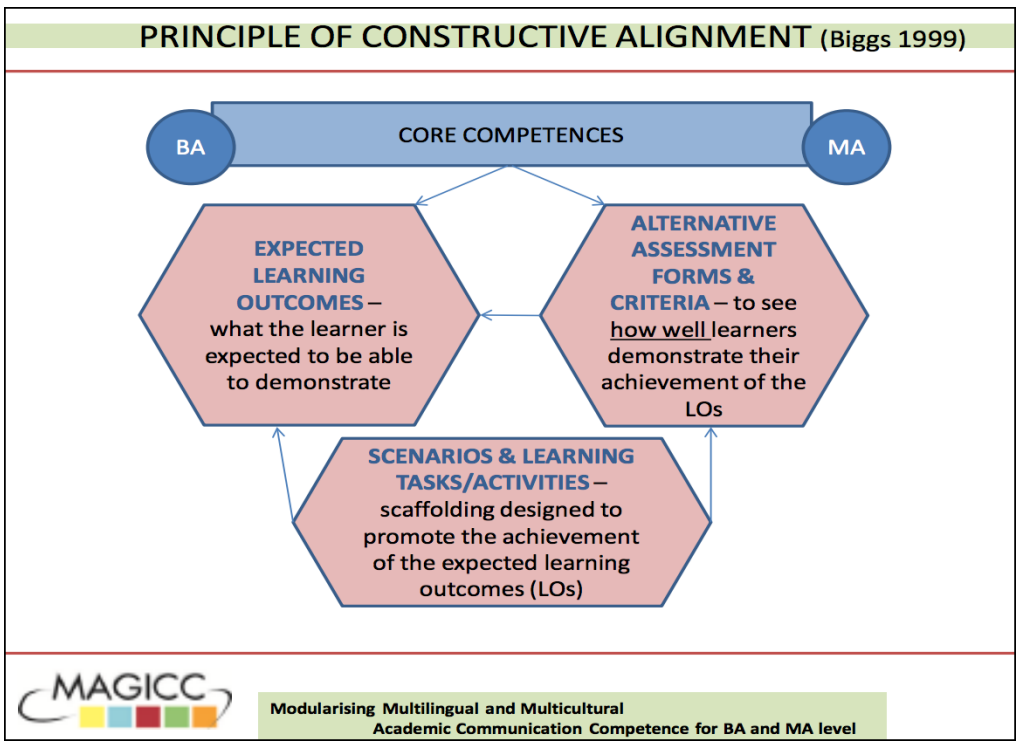

\section{Step 3: Checking the social relevance of the conceptual framework}

An important element in the implementation of the Bologna Process for EHEA was the social relevance of higher education. The MAGICC project attended to this requirement by conducting two consultations with stakeholders, with an aim to ensuring the relevance of the conceptual framework and the learning outcome descriptions included. Another aim was to communicate the objectives and expected outcomes of the project to a wider circle of potential future users as well as to explore possible ways of implementing its future results.

The first consultation (autumn 2012) took place in all participating universities in the form of guided interviews based on pre-established questionnaires in 
order to facilitate analysis and allow comparability of the results. Three different questionnaires were designed for three stakeholder groups: students, faculty, and employers. Besides a series of general questions specific to the stakeholder groups, the questionnaires contained the same sets of learning outcome descriptions in the following domains to allow comparison: academic communication competences (receptive and productive skills), employability skills, multilingual and multicultural strategies and competence, lifelong learning skills and workrelated language and communication skills. The different stakeholder groups were invited to rate these sets of competences in relation to their importance for study purposes and/or for the global labour market and also indicate in which languages these competences are required. The stakeholders also suggested during which university cycle (BA and/or MA) these competences should be developed.

All learning outcomes listed in the questionnaires were perceived as relevant by the stakeholder groups. Although there was much convergence in the perceptions, receptive skills were in general seen as particularly important for the BA cycle, whereas productive skills (particularly writing) were of greater importance for the MA cycle. This preference was partly due to the disciplinary field, programme requirements, and specific academic cultures, and related in particular to conceptualising and communicating information, knowledge and expertise in a multilingual and multicultural context. According to the student, faculty, and employer representatives interviewed, professional, lifelong learning, and intercultural skills should, therefore, be developed in both cycles. Regardless of the general consensus on the importance of the listed learning outcomes for academic competence building, there were also some differences between the three stakeholder groups in how much emphasis they placed on certain skills and strategies, as exemplified in Figure 2 and Figure 3 below.

As the figures indicate, the employers in the consultation perceived all other skills except lifelong learning as clearly more important than the two other stakeholder groups did. On the other hand, student answers on, for example, the importance of adapting communication may only reflect their inexperience with multilingual and multicultural communication, whereas they saw lifelong 
learning and study skills as very important to develop, as did the faculty representatives interviewed.

Figure 2. Stakeholders' (\%) perceived importance of skills development in the management of information, teamwork, intercultural awareness and ability to adapt to communication in multilingual and multicultural contexts

\section{EXAMPLE OF STAKEHOLDER VIEWS:} perceived importance of skills development

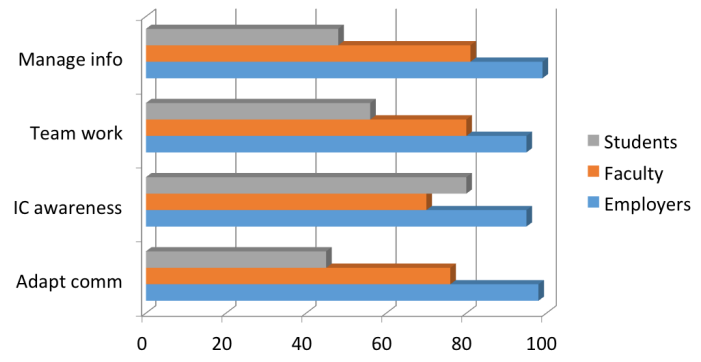

Figure 3. Stakeholders' (\%) perceived importance of skills development, lifelong learning, and communication in multilingual and multicultural social situations

\section{EXAMPLE OF STAKEHOLDER VIEWS:} perceived importance of skills development

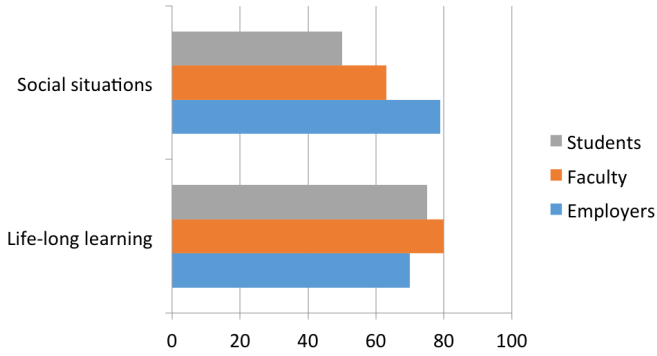


The second stakeholder consultation (February 2013) was organised as a dissemination and feedback event. During the event, two panel discussions with invited guests from all the partner countries were arranged. The first group of panellists comprised specialists in different domains, such as university policy, psychology, international relations and labour market research. The second panel was composed mostly of specialists in the area of languages. Both groups were asked to give feedback on the conceptual framework from the viewpoint of their expertise and experience, as well as to suggest recommendations for implementation.

In general, the panelists saw MAGICC as an important project which raises awareness about the dimensions of multilingual and multicultural competences and the interdependency of languages, thus making the role of languages in mediating and constructing knowledge important and transparent. Moreover, well-developed skills and strategies were seen as a clear competitive edge for graduates' employability. However, for implementation, the conceptual framework needed more concrete and generic examples and guidance for users to concretise the value of developed multilingual and multicultural competences for employers, staff and students.

The conceptual framework was revised on the basis of the two consultations. Some concepts and learning outcome descriptions, for example, were clarified, and some user guidance added. The end result, however, remained: the framework was perceived as socially relevant and potentially useful as a reference document for the higher education level.

\section{Concluding remarks}

The multilingual and multicultural approach advocated by the project aims at promoting students' use and expansion of their entire multilingual repertoires, thus enabling both wider access to learning and negotiation of meanings in interaction. In addition, it aims at maintenance and respect of diversity as an intrinsic value to full participation in a globalised society. 
Achieving these aims requires a mental change in attitudes and practices, a move from a monolingual mindset to appreciating the coexistence of languages in communication and interaction. Moreover, it requires acknowledgment of the significance of individuals' agency and the use of one's repertoire, because they are enabling factors for multilingualism to become manifest and grow (see Blommaert et al. 2005). From the pedagogical point of view, new skills and strategies need to be developed in higher education, including negotiation strategies for meaning, intercomprehension and mediation strategies, codeswitching and translanguaging strategies, and other tools to cope with multilingual and multicultural realities. Avoidance of so-called correctness is also an issue, because partial competences are an important element of an individual's communication repertoire. Naturally, in certain situations (e.g. formal writing), accuracy remains an important criterion, but diversification of instructional designs and approaches is equally important. It is to this effect that the MAGICC project has attempted to contribute.

The conceptual framework itself is mainly addressed to language specialists and policy makers. It is an open resource, including learning outcome descriptions and transnational tools for integrating academic, intercultural and lifelong learning dimensions in the graduate's multilingual and multicultural repertoire building in higher education. Moreover, it is operationalised as scenario activities, multidimensional performance assessment and an academic ePortfolio, which expands the features of the Council of Europe's ELP to match new needs in higher education and to improve the visibility and recognition of the specific nature of academic communication competences in relation to employability. Through this operationalisation, the outcomes of the MAGICC project are designed to serve students, teachers, faculties and employers.

The project work is extremely well documented and fully available on the project website, including learning outcome descriptors in English, German and French and their assessment scales presented as an interactive reference as well as templates for building new pedagogical scenarios or adapting and combining existing ones for individual purposes. The consultation questionnaires are available in all partner languages, and all partner universities also made 
implementation plans and reported on their outcomes. It is only by actively using the project outputs that the potential of the innovative elements designed for higher education language teaching and learning purposes can become manifest for the stakeholders envisaged in the project.

\section{References}

Adamson, H. D. 1993. Academic competence. theory and classroom practice: preparing ESL students for content courses. London: Longman.

Baume, D. 2009. Writing and using good learning outcomes. Leeds: Leeds Metropolitan University. Retrieved from https://www.leedsbeckett.ac.uk/partners/files/Learning Outcomes.pdf

Biggs, J. 1999. Teaching for quality learning at university: what the student does. Buckingham: The Society for Research into Higher Education and Open University Press.

Blommaert, J., Collins, J. \& Slembrouck, S. 2005. Spaces of multilingualism. Language \& Communication, 25 (3), 197-216. doi:10.1016/j.langcom.2005.05.002

Bologna Process. 2020. The European higher education area in the new decade. Retrieved from http://www.ehea.info/Uploads/Declarations/Leuven_Louvain-la-Neuve_ Communiqu\%C3\%A9_April_2009.pdf

Bologna Working Group. 2005. A framework for qualifications of the European higher education area. Copenhagen: Ministry of Science, Technology and Innovation. Retrieved from http://www.ehea.info/Uploads/qualification/QF-EHEA-May2005.pdf

Byram, M. 2008. From foreign language education to education for intercultural citizenship: essays and reflections. Clevedon: Multilingual Matters.

CARAP. 2011. A framework of reference for pluralistic approaches to languages and cultures. Retrieved from http://carap.ecml.at

Cottrell, S. 2003. The Study Skills Handbook. New York: Palgrave Macmillan.

Council of Europe: Language Policy Division. 2006. Plurilingual education in Europe. 50 years of international co-operation. Retrieved from http://www.coe.int/t/dg4/linguistic/ source/plurinlingaleducation_en.pdf

EHEA. 2012. The European higher education area in 2012: Bologna process implementation report. Brussels: EACEA P9 Eurydice. doi:10.2797/81203 


\section{Chapter 5}

Forster Vosicki, B. 2014. Modularising multilingual and multicultural academic communication competence: rationale and purpose of the MAGICC project. Paper presentation in the 13th International CercleS Conference, programme and abstracts, 4-6 September 2014, Fribourg, Switzerland. Retrieved from http://www.cercles2014.org/ docs/programme_and_abstracts.pdf

INCA Assessor Manual. 2004. Intercultural competence assessment (INCA). Retrieved from https://www.yumpu.com/en/document/view/8814059/assessor-manual-inca-project

Jørgensen, J. N. 2008. Polylingual languaging around and among children and adolescents. InternationalJournalofMultilingualism, 5(3),161-176. doi:10.1080/14790710802387562

LanQua quality model 2010. Retrieved from http://speaqproject.files.wordpress.com/2012/02/ lanqua-quality-model_eng.pdf

Lenz, P. \& Berthele, R. 2010. Assessment in plurilingual and intercultural education. Strasbourg: Council of Europe: Language Policy Division. Retrieved from http://doc.rero. ch/record/31422/files/Assessment2010_Lenz_Berthele_EN.pdf

Lähteenmäki, M., Varis, P. \& Leppänen, S. 2011. Editorial: The shifting paradigm: towards a re-conceptualisation of multilingualism. Apples: Special issue on Mediated Multilingualism, 5 (1), 2-11.

MAGICC Conceptual Framework. 2013. Retrieved from http:/www.unil.ch/files/live//sites/ magicc/files/shared/Revised_Conceptual_Framework_MAGICC.pdf

Møller, J. S. 2008. Polylingual performance among Turkish-Danes in LateModern Copenhagen. International Journal of Multilingualism, 5 (3), 217-236. doi:10.1080/14790710802390178

Moon, J. 2006. Linking levels, learning outcomes and assessment criteria - EHEA version. Retrieved from http://spectare.ucl.slu.se/adm/sus/2008/plagiarism_eng/ JennyMoonExercise.pdf

Räsänen, A. 2014. Towards the MAGICC conceptual framework. Paper presentation in the 13th International CercleS Conference, programme and abstracts, 4-6 September 2014, Fribourg, Switzerland. Retrieved from http://www.cercles2014.org/docs/programme and_abstracts.pdf 


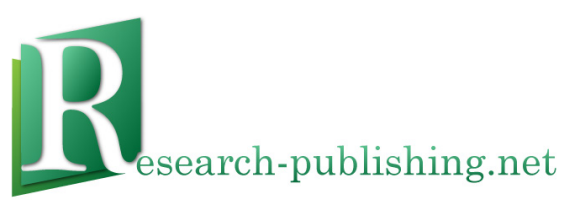

Published by Research-publishing.net, not-for-profit association Dublin, Ireland; Voillans, France, info@research-publishing.net

(C) 2015 by Research-publishing.net (collective work)

Each author retains their own copyright

Voices of pedagogical development - Expanding, enhancing and exploring higher education language learning Edited by Juha Jalkanen, Elina Jokinen, \& Peppi Taalas

Rights: All articles in this collection are published under the Attribution-NonCommercial -NoDerivatives 4.0 International (CC BY-NC-ND 4.0) licence. Under this licence, the contents are freely available online (as PDF files) for anybody to read, download, copy, and redistribute provided that the author(s), editorial team, and publisher are properly cited. Commercial use and derivative works are, however, not permitted.

\section{()ㅛ $\Theta \Theta$}

Disclaimer: Research-publishing.net does not take any responsibility for the content of the pages written by the authors of this book. The authors have recognised that the work described was not published before, or that it is not under consideration for publication elsewhere. While the information in this book are believed to be true and accurate on the date of its going to press, neither the editorial team, nor the publisher can accept any legal responsibility for any errors or omissions that may be made. The publisher makes no warranty, expressed or implied, with respect to the material contained herein. While Research-publishing.net is committed to publishing works of integrity, the words are the authors' alone.

Trademark notice: Product or corporate names may be trademarks or registered trademarks, and are used only for identification and explanation without intent to infringe.

Copyrighted material: Every effort has been made by the editorial team to trace copyright holders and to obtain their permission for the use of copyrighted material in this book. In the event of errors or omissions, please notify the publisher of any corrections that will need to be incorporated in future editions of this book.

Typeset by Research-publishing.net

Cover design by (C) Antti Myöhänen

ISBN13: 978-1-908416-25-4 (Paperback - Print on demand, black and white)

Print on demand technology is a high-quality, innovative and ecological printing method, with which the book is never 'out of stock' or 'out of print'.

ISBN13: 978-1-908416-26-1 (Ebook, PDF, colour)

ISBN13: 978-1-908416-27-8 (Ebook, EPUB, colour)

Legal deposit, Ireland: The National Library of Ireland, The Library of Trinity College, The Library of the University of Limerick, The Library of Dublin City University, The Library of NUI Cork, The Library of NUI Maynooth, The Library of University College Dublin, The Library of NUI Galway.

Legal deposit, United Kingdom: The British Library.

British Library Cataloguing-in-Publication Data.

A cataloguing record for this book is available from the British Library.

Legal deposit, France: Bibliothèque Nationale de France - Dépôt légal: septembre 2015. 